\title{
Conditions for Development of the Private Health Insurance in Poland
}

\author{
Lukasz Jasinski \\ Maria Curie Skłodowska University, Lublin, Poland
}

\begin{abstract}
The main purpose of this paper is to analyze the chosen conditions, encouraging and hindering the development of the private health insurance in Poland. Individual kinds of private health insurance were identified based on the actual market offer. The main part of the work constitutes description and analysis of the main and characteristic for Poland conditions, influencing the private health insurance. Moreover, the work includes partial comparative analysis of Polish and chosen European healthcare systems. These systems vary in different forms of financing of health services or the amount of expenses on the healthcare system. Therefore, private health insurances function in many countries on different principles, what influences significantly their role in the healthcare system. In Poland, private health insurances exist as supplementary insurances related to the basic system. It is allowed, to a certain extent, competition with the public system. Relatively better quality of health services available through private insurances is one of factors for the dynamic growth of the value of this market in Poland in the last years.
\end{abstract}

Keywords: private health insurance, group health insurance, individual health insurance, healthcare system, health

Public healthcare system in Poland deals with some financial difficulties. Social and economic factors as well as principles of financing access to the medical services, based mostly on compulsory premiums, influence this fact. In Poland, there is currently functioning a system of compulsory health insurance, which is a basic (main) system. In this system managing, financial, supervisory, and controlling functions are divided between the public institutions: Ministry of Health, National Health Fund (NFZ), and territorial governments. NFZ is financing the healthcare services and contracts public and non-public service providers. Ministry of Health supervises the activities of NFZ (i.e., minister in charge for the health issues) and Ministry of Finance supervises the financial economy of the fund ${ }^{1}$. General structure of the public healthcare system in Poland is presented in Figure 1.

Private health insurance functioning in Poland is voluntary and has a supplementary character, in other words, increasing the scope of provided services, however, without the possibility to resign from the participation in the public system (Handschke, 2013). It is not possible to get a tax allowance for the private purchase of the health insurance. In spite of it, in the last years, the market of private health insurance is developing in Poland very dynamically and the average growth pace amounts to $30 \%$ in a year (Surmacz, 2012). Operational conditions and the scope of insurance are determined by the insurance companies. At the moment,

Corresponding author: Lukasz Jasinski, Ph.D. candidate, master of finance and accounting, Faculty of Economics, Maria Curie Skłodowska University; research fields: Austrian School of Economics, private health insurance, health care systems, life insurance, saving, and precious metals. E-mail: lukasz.jasinski@poczta.umcs.lublin.pl.

1 See: Outline of the health care system. Poland 2012. (2012). P. 43. Retrieved from http://www.nfz.gov.pl/akademia/pliki/ Polska_2012.pdf. 
there is no legislation from above defined precisely determining the scope of the private health insurance. Moreover, the insurer is not obliged to accept all the willing to be insured, not regarding the age and health state (as wise in the public system). The insurers can impose limits and exclusions, what they do, depending on the kind and form of the insurance.

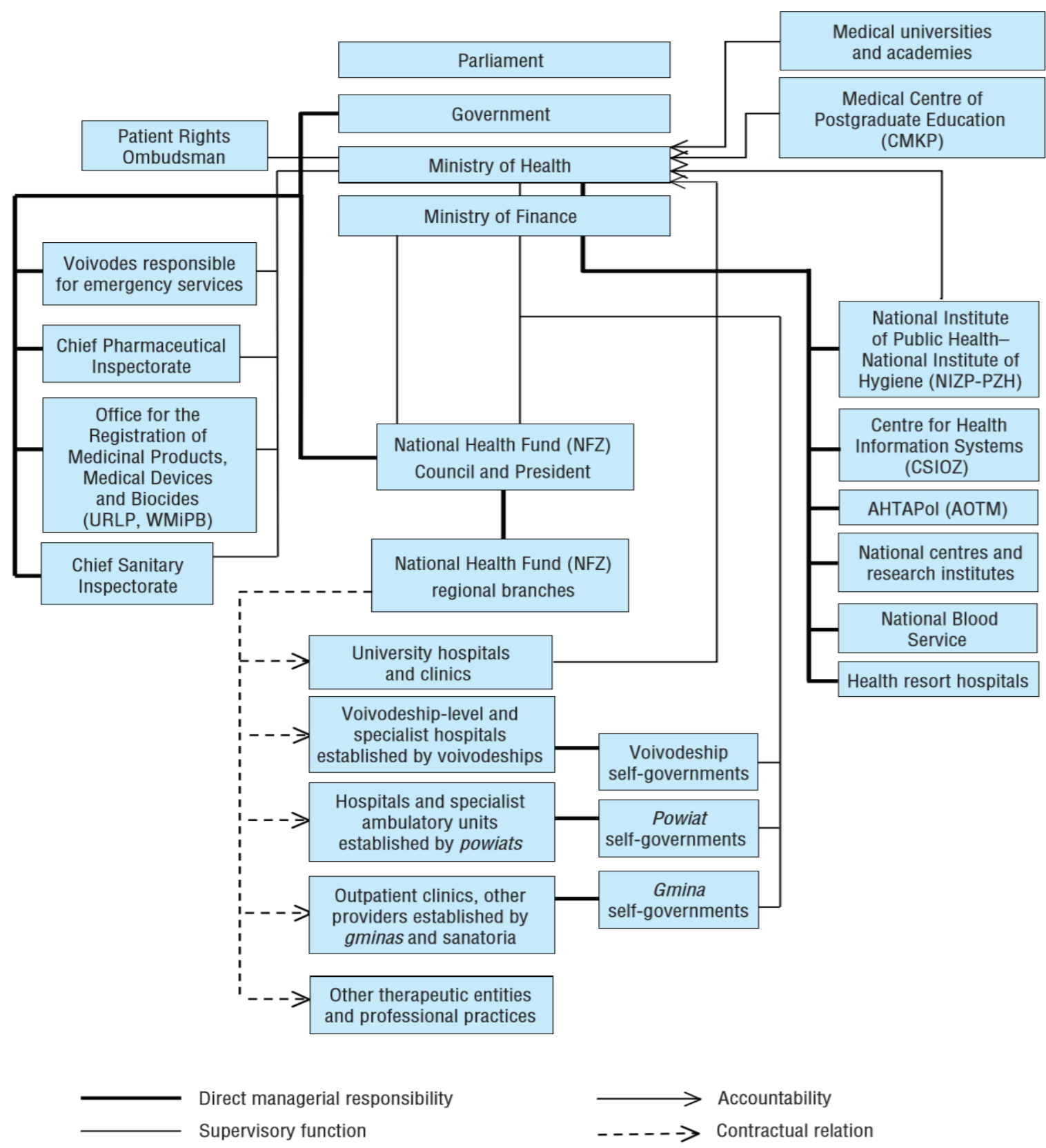

Source: Adapted from Kuszewski \& Gericke, 2005

Note: Administrative units are gmina (municipality), powiat (district) and voivodeship (or region).

Figure 1. General structure of the public healthcare system in Poland. Source: see the website ${ }^{2}$.

\footnotetext{
${ }^{2}$ See: Poland: Health system review. Health Systems in Transition, 13(8), 15. Retrieved from http://www.euro.who.int/_data/ assets/pdf_file/0018/163053/e96443.pdf.
} 
Such form of the healthcare system in Poland results in the fact, which most of the expenses come from the public, compulsory insurance premiums $(64 \%)$ and the share of the private health insurance is marginal $(1 \%)$. Also, the share of government expenses $(6 \%)$ is relatively low, what is characteristic for the healthcare systems based on the insurance model. In turn, a big share of direct payments (26\%) may suggest that Poles prefer to allocate their private money in this form of financing rather than in the private insurance. Comparison of the expenses structures for healthcare in Poland and in the chosen European countries is presented in Figure 2.

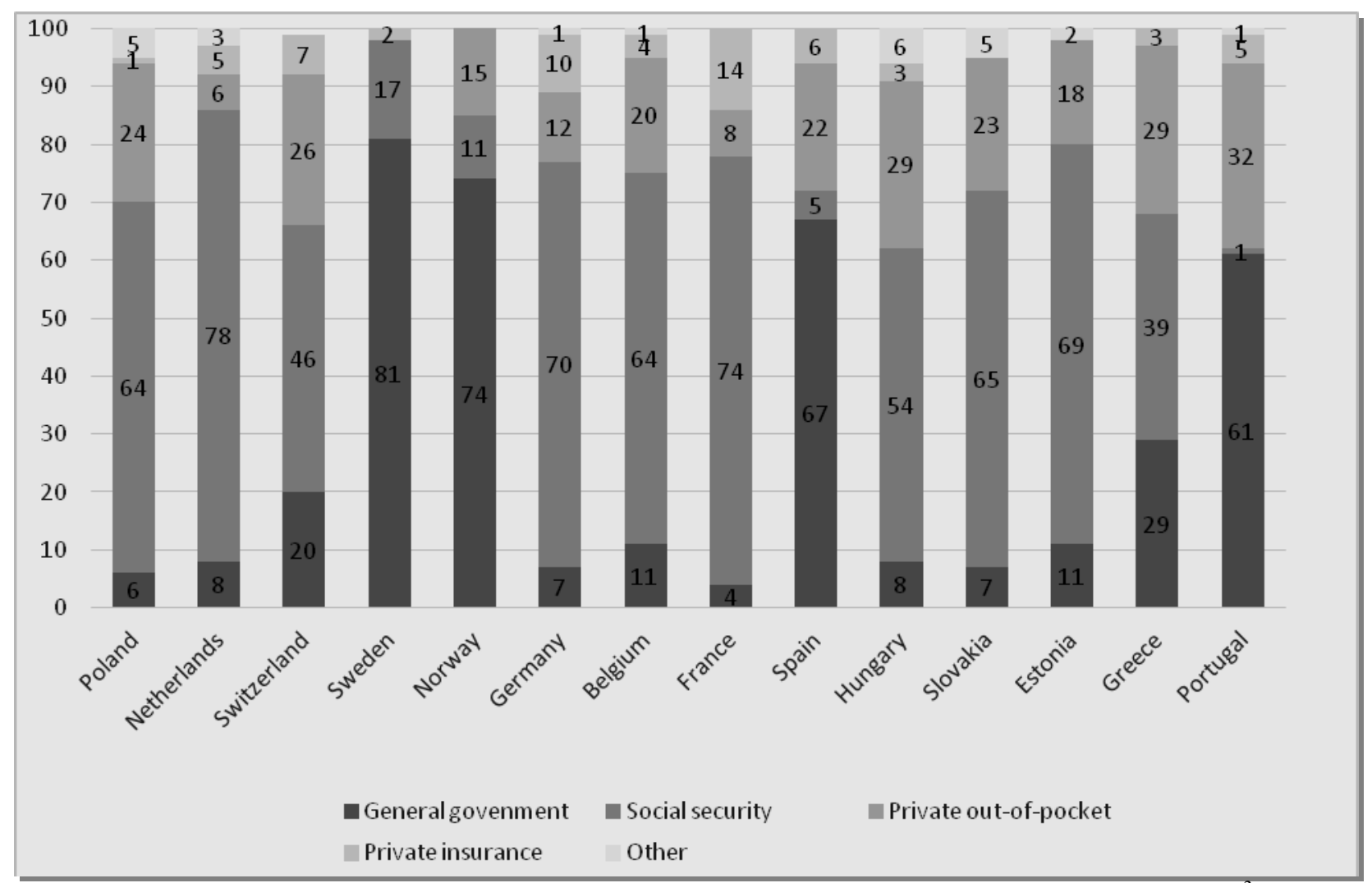

Figure 2. Structure of expenses for healthcare (in percentages) in the chosen countries. Source: see the website ${ }^{3}$.

Data in Figure 2 demonstrate that the main financing source for the health services in the chosen countries is the public health insurance or the government expenditures (characteristic for the Nordic countries and South of Europe pay-as-you-go). The share of the private health insurance is low and results mainly from the obligation to join the basic systems. The greatest share of the private health insurance is observed in France, where $93 \%$ of the population makes use of the complementary health insurance ${ }^{4}$. However, in some countries (e.g., Netherlands, Switzerland), the basic system of health insurance is functioning based on the obligatory private health insurance ${ }^{5}$. Because of the differences between Poland and the other countries, the main purpose

\footnotetext{
3 See: OECD. Health at glance 2014, p. 129. Retrieved from http://www.oecd-ilibrary.org/docserver/download/8114211e.pdf? expires $=1422967188 \&$ id $=$ id\&accname $=$ guest \&checksum $=0855 \mathrm{E} 90196 \mathrm{~A} 7 \mathrm{~B} 40326 \mathrm{D} 2965 \mathrm{C} 1 \mathrm{~A} 6 \mathrm{~A} 10 \mathrm{~EB}$.

${ }^{4}$ See: Role of the private health insurance in the healthcare system. How does it influence the access to services, innovations and medicines-Key theories and recommendations, p. 9. Retrieved from https://piu.org.pl/public/upload/ibrowser/110908 PIU_Infarma_Sequence_opracowanie_dodatkowe_ubezpieczenia.pdf.

5 See: Role and functioning of the additional health insurance in the contemporary healthcare systems-Analysis and recommendations for Poland, p. 15. Retrieved from http://gu.com.pl/static/czol-raport.pdf.
} 
of this paper is to analyze the chosen conditions, encouraging and hindering the development of private health insurances in Poland.

\section{Definition of the Private Health Insurance}

Mentioning the health insurance, there is its definition to be determined at the beginning, what will enable to determine the role of private health insurance in financing the access to the health services in Poland.

Private health insurance is defined as a voluntary insurance product, under which the insured, in turn for payment of the insurance premium, receives free or partially refundable by the insurance institution access to the chosen healthcare units and certain medical services, depending on the offered scope of insurance (Iwanicz-Drozdowska, 2013). The subject of the insurance is the health of the insured person. At this point, it is to be noted that there are also other kinds of private insurance, where the subject of the insurance is also the health of the insured person. Following kinds of such insurance can be classified: insurance covering disease risk, accident risk, and disability insurance. The insured person receives certain money consideration for the stay at the hospital, health impairment as a result of an accident or finding of disability. The above mentioned kinds of the insurance risk usually function as additional contracts, increasing the basic scope of the individual and group (staff) life insurances. They do not secure the access to the medical services and solely guarantee adequate financial reimbursement for the insured person as a result of certain circumstances (disease, accident).

\section{Private Health Insurance in Poland}

According to the statistics from 2010, about 450,000 people made use of the private health insurances. Group (staff) insurance is used by around 400,000 people and the individual insurance by no more than 50,000 people $^{6}$ (from 38.5 million of Poles ${ }^{7}$ ). Among different kinds of private expenses for health, the share of the private insurances is low and in 2010 amounted to $0.5 \%$. Poles mostly make use of direct payments. Other private form of financing the access to the medical services constitutes the so-called medical subscriptions offered by private medical networks. Person having such subscription can make use of the access to the medical services offered by the healthcare units of the given medical network. Differences between the private health insurance and medical subscriptions result from the fact that these products are offered by different subjects of the private market (insurance companies and private medical networks). According to some studies on the medical market, from the point of view of the definition or even comparative reports on the health insurance market, medical subscriptions are to be qualified to the supplementary (parallel) health insurance ${ }^{8}$. Share of the private health insurances in the private health expenditures is presented in Figure 3.

\section{Group and Individual Health Insurance}

Group health insurance (constituting the main part of the private insurances in Poland) complement in the last years the basic offer of the insurance companies in the group insurance market, which is the employee life

\footnotetext{
${ }^{6}$ See: Role of the private health insurance in the healthcare system. How does it influence the access to services, innovations and medicines_Key theories and recommendations, p. 11. Retrieved from https://piu.org.pl/public/upload/ibrowser/110908_PIU_ Infarma_Sequence_opracowanie_dodatkowe_ubezpieczenia.pdf.

7 See: Area and population in the territorial profile in 2013, p. 17. Retrieved from http://stat.gov.pl/cps/rde/xbcr/gus/1 powierzchnia_i_ludnosc_przekroj_terytorialny_2013.pdf.

${ }^{8}$ See: Role of the private health insurance in the healthcare system. How does it influence the access to services, innovations and medicines-Key theories and recommendations, p. 13. Retrieved from https://piu.org.pl/public/upload/ibrowser/110908_PIU_ Infarma_Sequence_opracowanie_dodatkowe_ubezpieczenia.pdf.
} 
insurance. Group life insurance is a separate product for big corporations as well as for small family companies with a few employees. This solution, because of its group character, can bring the insured persons some tangible benefits. One of such benefits is a lower premium to be paid by the insured. By the premium determination, the risk of the whole group, not of the individuals, is taken into account.

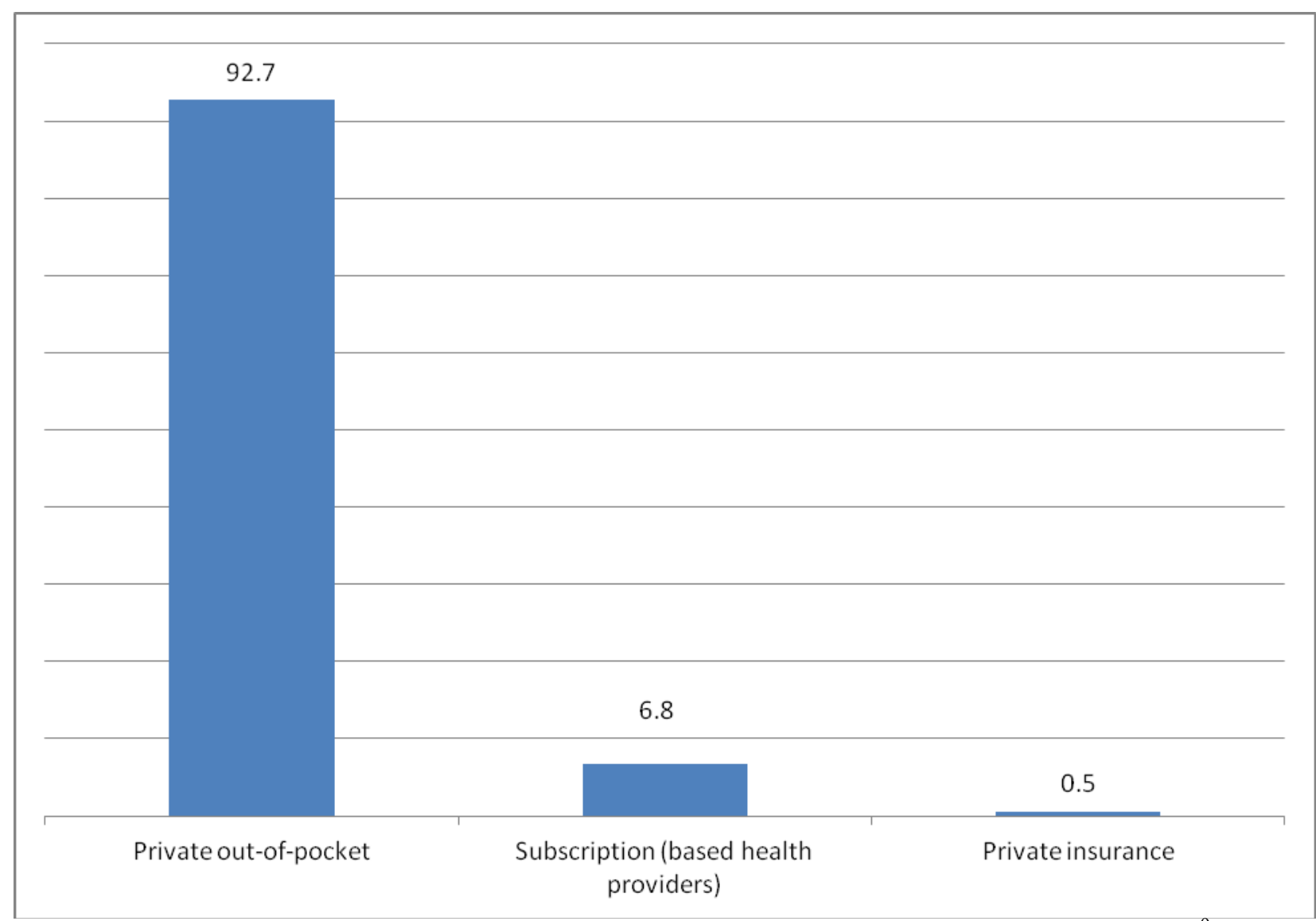

Figure 3. Share of insurance in private health expenses in Poland in 2010 (in percentage). Source: see the website ${ }^{9}$.

In Poland, there is also functioning private hospital insurance (group hospital insurance as well as supplementary contracts to the individual insurances), financing or refunding costs of the operations of the insured in the private healthcare units. However, they constitute a marginal share in the health insurance market.

Health insurances for the employees have some limits. Here we can point out that having a particular group insurance depends on the workplace. In case of lost or change of job, the ensured person cannot keep the particular insurance because of the expired employment with the former employer. As of today, there is no possibility to continue such insurance individually (on changed conditions), what is possible in case of the group life insurance. The next problem is that the insurance expires after the insured person reaches certain age. Although there are some limits, the group health insurance starts to be more popular, mainly because of the wide range of the insurance and relatively low premium.

\footnotetext{
${ }^{9}$ See: Role of the private health insurance in the health care system. How do they influence the access to services, innovations and medicines-Key theories and recommendations, p. 12. Retrieved from https://piu.org.pl/public/upload/ibrowser/110908_ PIU_Infarma_Sequence_opracowanie_dodatkowe_ubezpieczenia.pdf.
} 
Because of its character group insurances limit, to some extent, the autonomy of the individual employees, in bigger companies, during the negotiations between the insuring company and the employees, usually represented by the human resources department, it is difficult to consider all the needs of the employees. There are also unfavorable situations, when the priority in the negotiations is the financial interest of individuals delegated by the employer to handle the insurance, not the interest of the employees. It is completely different, when the insured person closes the contract individually. Then, he has greater possibility to tailor the scope of insurance to his needs, and in this way, gets independent from his former workplace. The scope of the individual insurance is similar as in the group insurance with the difference that the insured person has to pay a higher premium. Insurance companies usually apply individual premiums, depending on the scope of insurance. There is also a possibility (as in the group insurance) to cover the children and the spouse (or partner) of the insured person.

It is worth adding that in 2013, some insurance companies implemented new solutions on the market on financing access to the medical services functioning as supplementary contracts to the individual life insurance. The scope of supplementary contracts applies to situations of serious illness. In case of a serious illness, the insured person instead of getting a standard payment of the insurance amount, makes use (up to certain amount) of the national and international private health care units.

\section{Development of the Private Health Insurance in Poland}

\section{Factors Encouraging the Development}

Unreliability if the public healthcare system. Despite of the universal nature of the public system guaranteeing free access to healthcare, one can observe permanent growth of the popularity of the market solutions (including insurance). According to estimates only in 2014, the pace of growth of the whole private healthcare market in Poland grew by $5.7 \%$ and from 2005 by about $88 \%{ }^{10}$. Moreover, it is worth adding that Poland has to make up a big distance comparing with countries of Western Europe as far as the quality and the level of expenditures on healthcare are concerned. The Polish healthcare system takes far positions in the rankings on the healthcare quality in the individual countries. One of the more known studies evaluating healthcare systems in Europe is the ranking EuroHealth Consumer Index (EHCI) ${ }^{11}$, where in 2014 Poland took place 31 out of 36 countries and Scotland (collecting 511 out of 1,000 points). The authors of the report pay special attention to the fact that Poland as one of the few countries included in the ranking had a worse result than in the year 2013 (521 points). As for a big Central European country, being a member country of the European Union (EU), the result for Poland is indisputably poor ${ }^{12}$. Detailed comparison of the quality of the healthcare systems in the chosen European countries is presented in Figure 4.

Moreover, Poland ranks poorly under other European countries, as far as the expenses for healthcare related to Gross Domestic Product (GDP) are concerned. In 2012, Poland has spent $6.8 \%$ of GDP on

\footnotetext{
10 See: Market of the private healthcare in Poland: Growth by 5\% in the period 2012-2014. Retrieved from http://www.pmrpublications.com/press-releases/336/rynek-prywatnej-opieki-zdrowotnej-w-polsce-wzrost-o-5-w-latach-2012-201 4.

${ }^{11}$ Ranking EuroHealth Consumer Index evaluates the European healthcare systems according to six criteria: patient rights and information, accessibility (waiting times for treatment), outcomes, range and reach of services provided, prevention and pharmaceuticals. The total score determines general quality of the healthcare systems in the individual countries.

12 See: EuroHealth Consumer Index 2014. Retrieved from http://www.healthpowerhouse.com/index.php?Itemid=55.
} 
healthcare, whereas the average for the countries of the EU (EU 28) is 8.7\%. For comparison, Netherlands and Switzerland have spent for healthcare $11.8 \%$ and $11.4 \%$ of GDP, respectively. The growth of expenditures on healthcare also influences the negative demographic tendencies in Poland and other European countries. In case of Poland (toward the poorly estimated public system), it is worth taking into consideration the greater share of private solutions (including health insurance) in financing the access to the medical services in the nearest future. The level of expenditures for healthcare in the individual countries related to GDP is presented in Figure 5.

Lack of detailed regulations concerning private health insurances. In Poland, apart from the acts regulating the insurance activity as itself, actually there is no legislation regulating which insurance companies (life or non-life) and under what conditions are allowed to offer private life insurance and what should be the scope of such insurance. It gives the insurance companies big freedom in creating and development of their own insurance products (individual as well as group products). Insurance companies of Type I (life) as well as Type II (non-life) may sell health insurances, although usually they belong to one capital group. Such conditions are favorable for the development of new products and the competition processes. This situation is also favorable for clients because of a big number of competing insurance companies. The market of the private health insurance in Poland is insatiable and has a big growth potential. According to the statistics of the Financial Supervision Authority (FSA) in Poland, there are registered 27 insuring companies of Type I (life) and 30 insuring companies Type II (non-life). Detailed information on subjects that can potentially offer health insurances is shown in Figure 6.

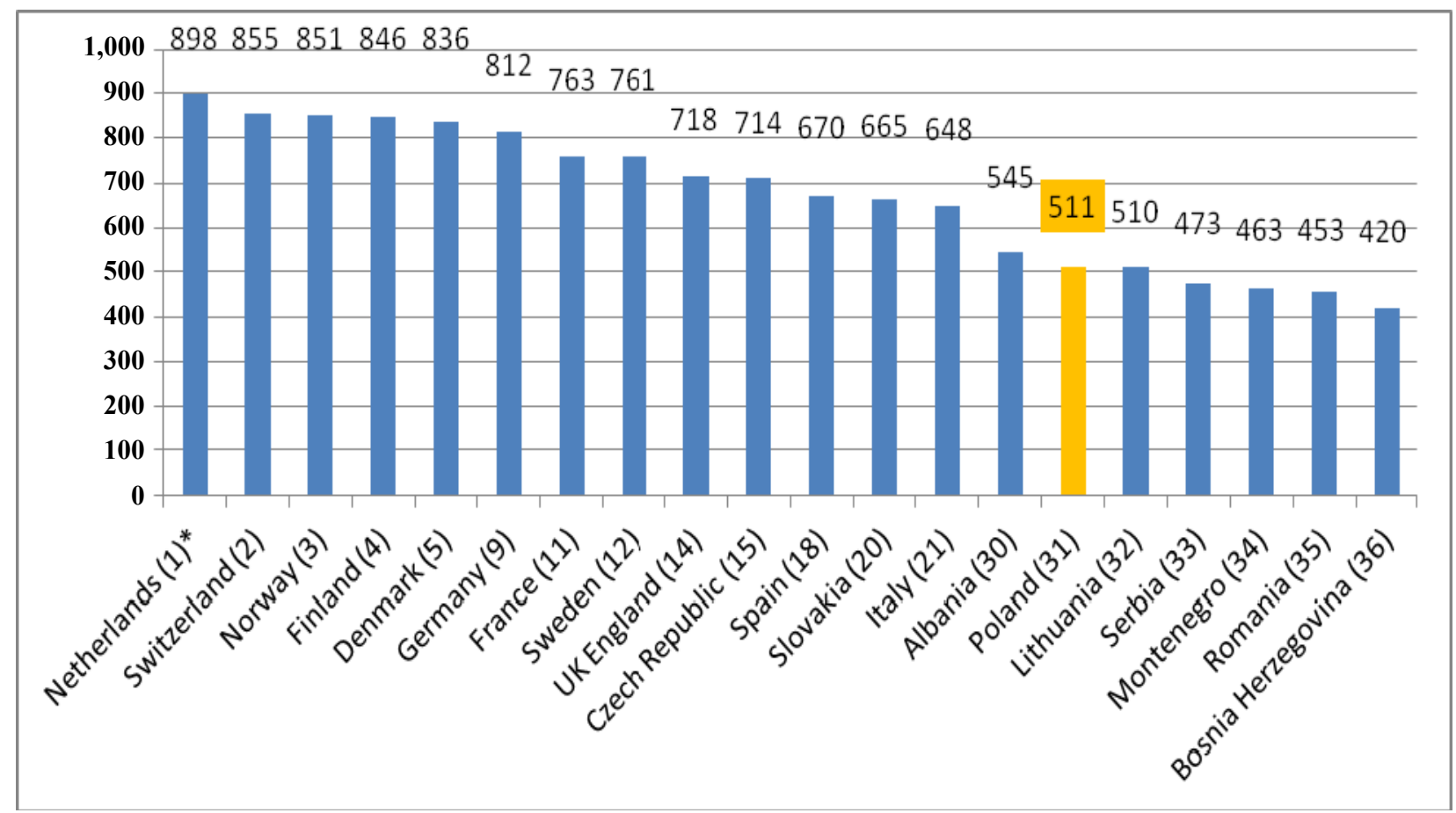

Figure 4. Quality of the healthcare systems (in points) in the chosen European countries. Source: EuroHealth Consumer Index $2014^{13}$. Note. ${ }^{*}$ means position of the given country in the ranking EuroHealth Consumer Index 2014.

13 See: EuroHealth Consumer Index 2014. Retrieved from http://www.healthpowerhouse.com/files/EHCI_2014/EHCI_ 2014_Index_matrix_A3_sheet.pdf. 


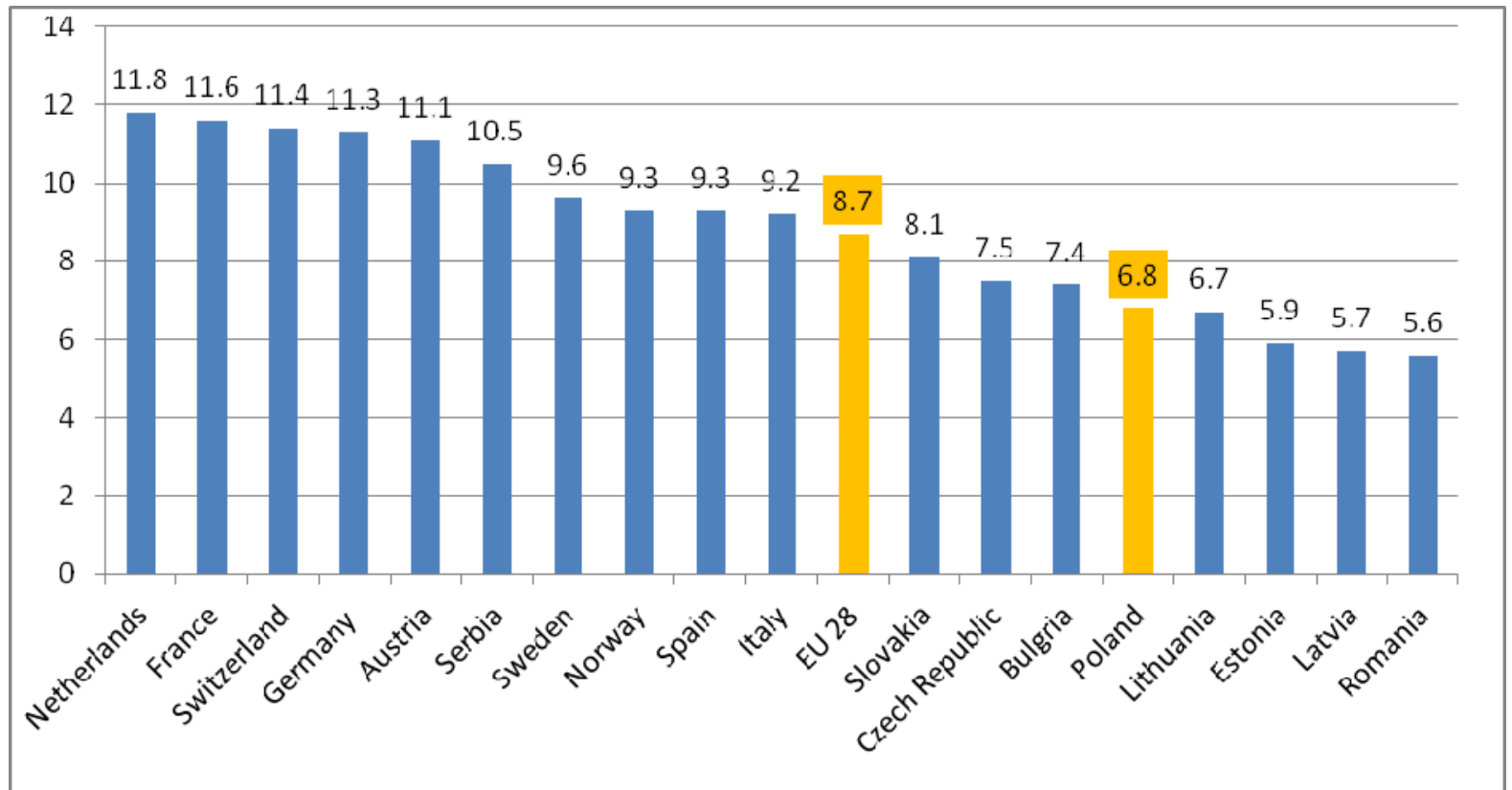

Figure 5. Health care expenditures in the year 2012 as percentage of GDP of the individual countries. Source: OECD. Health at Glance $2014(2014)^{14}$.

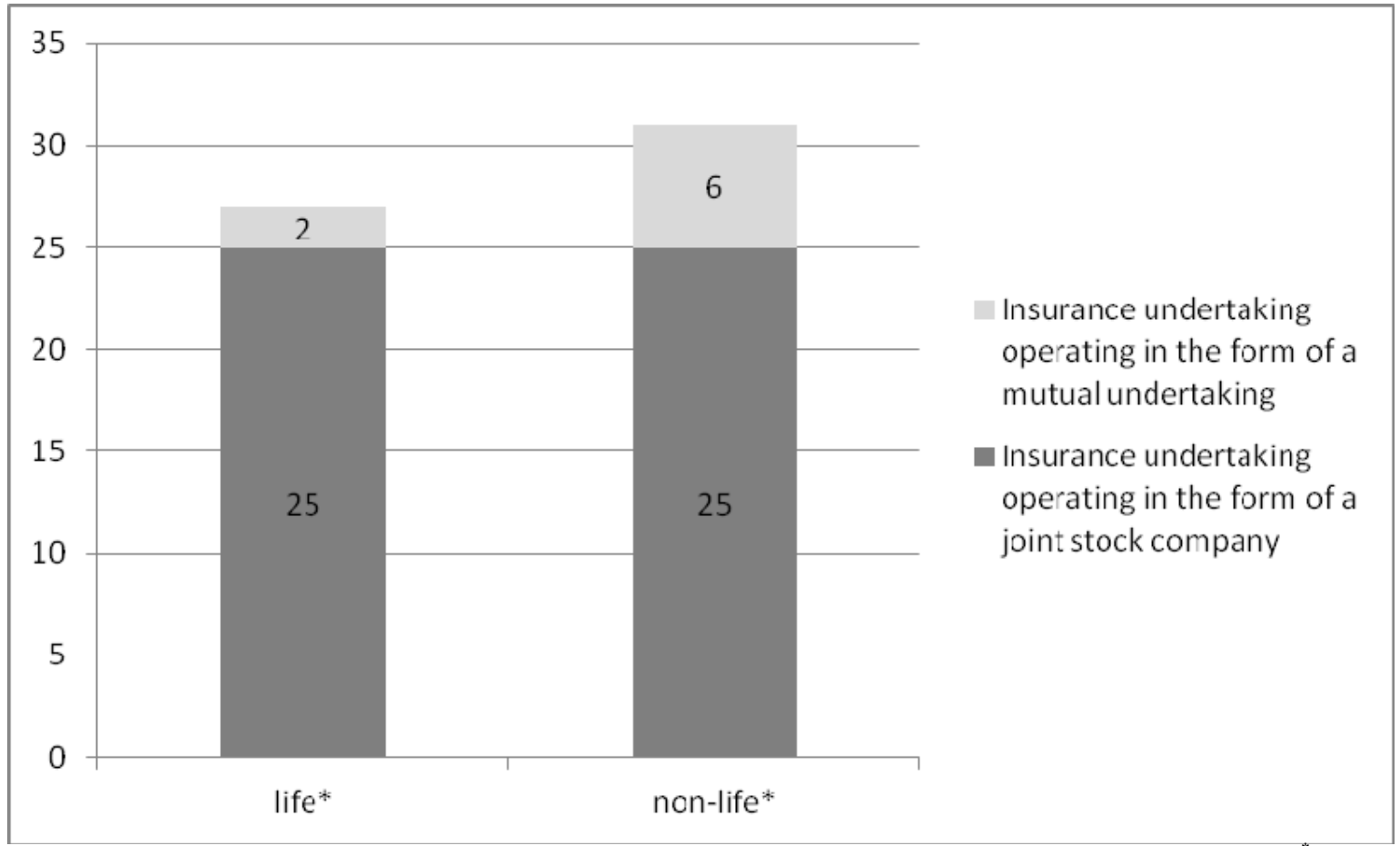

Figure 6. The number of the insurance companies that could potentially offer private health insurance. Note. ${ }^{*}$-life and non-life insurance companies with headquarters in Poland ${ }^{15}{ }^{16}$.

14 See: OECD. Health at glance 2014, p. 123. Retrieved from http://www.oecd-ilibrary.org/docserver/download/ 8114211e.pdf?expires=1422967188\&id=id\&accname=guest\&checksum=0855E90196A7B40326D2965C1A6A10EB.

15 See: Insurance companies with headquarters in Poland. Retrieved from http://www.knf.gov.pl/en/about the_market/Insurance/ Insurance_companies/Life_insurance_companies/insurance_companies.html.

${ }^{16}$ See: Non-life insurance companies with headquarters in Poland. Retrieved from http://www.knf.gov.pl/en/about_the_market/ Insurance/Insurance_companies/Non_life_insurance_companies/non_life_insurance_companies.html. 
Specificity of private health insurance. Because of the fact that health has a big value for people, they will be interested in solutions that will enable a better access to fast and efficient medical services. When the insured spends his funds on healthcare, he is interested in the best quality of the offered services. He also has the possibility to choose (freely) between the offers of the insurers, what makes him possible to adjust the offer better to his actual needs. Under present conditions, the market leads to the development of adequate social attitudes, where the individual members of a given community should actively take care of their health and feel responsible for it (Głowacka \& Zdanowska, 2013).

Participation of the employer in the private insurance costs. The employer may cover all or part of the expenditures on the health insurance of the employees. In this way, health insurance becomes one of the non-financial incentives that are very popular among the employees. Such possibility is usually offered by bigger companies or international corporations. It is important to add that in case when the employer covers all or part of the costs of the private health insurance, these costs are treated as the income of the employee, what formally increases his income, and at the same time, the amount of the income tax. In turn, the employer may charge these costs into deductible expenses. Figure 7 shows the popularity of the private health insurances (classed in the study to the basic medical care) among the employees in comparison to other non-financial incentives.

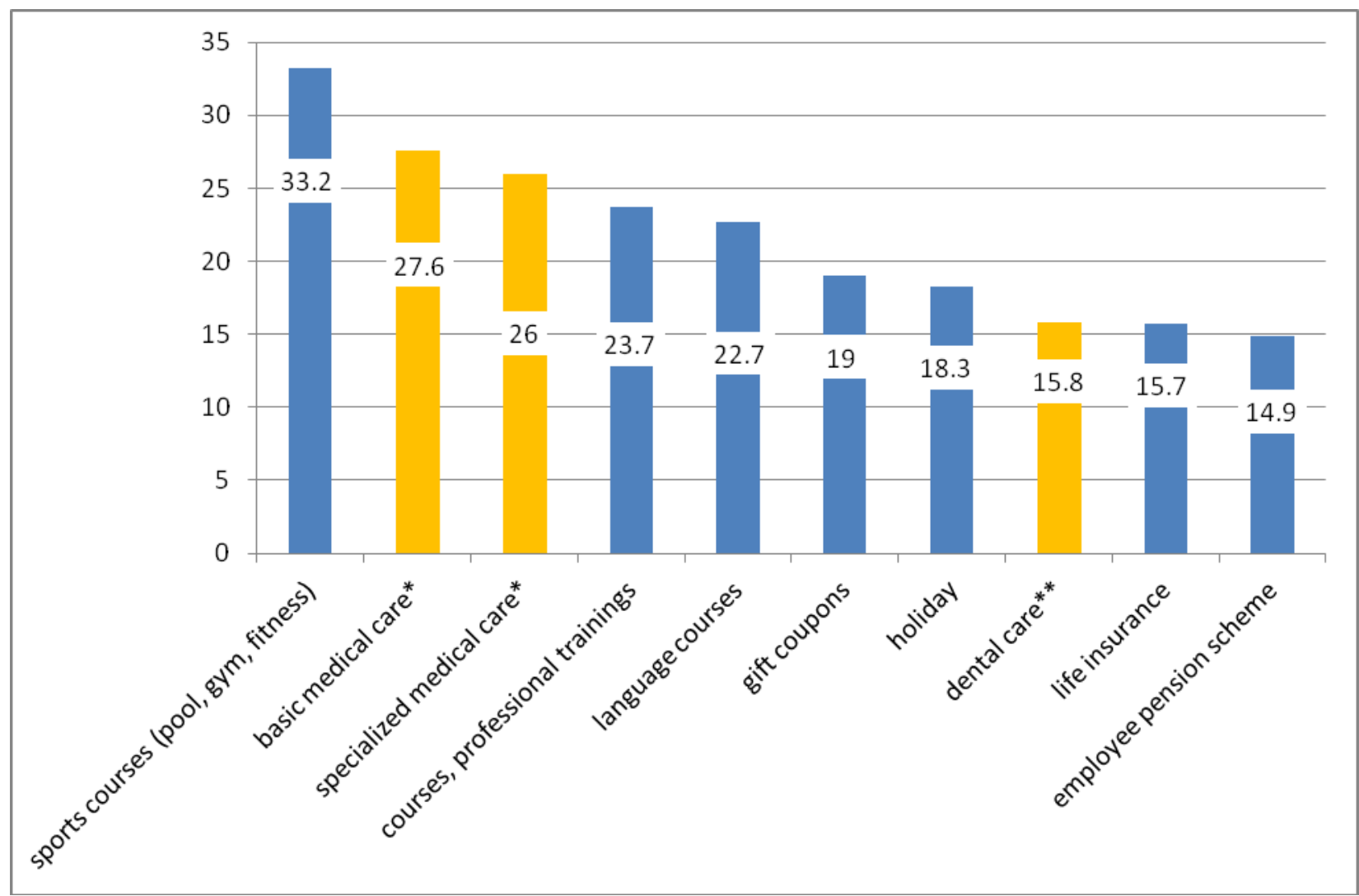

Figure 7. The most popular benefits expected by the employees in the companies that do not offer additional benefits in 2014 (in percentage). Source: Supplementary benefits from the point of view of the employees in 2014 (2014). Notes. " private health care insurance is one of the forms of financing access to the basic medical care and specific medical care; ${ }^{* *}$ dental care may be a part of the private health care or may be offered by the employer as a non-insurance non-financial benefit. 


\section{Factors Hindering the Development}

Costs of financing of the obligatory public healthcare system. Compulsory system of the health insurance requires imposing on the society certain tax and quasi-tax burdens. In this situation, the society has at its disposal less funds to spend on any purposes (including private health insurance). In spite of that, the private market can develop to some extent. In the Western European countries, high level of the tax wedge results from the high level of GDP per capita. In turn, in Poland, the level of the tax wedge does not translate into GDP per capita, what has more negative influence on the development of private health insurances. In Poland, the greatest share in the tax wedge $(35.6 \%)$ has the social security contributions $(15.3 \%$ to be paid by the employee and $14.4 \%$ to be paid by the employer; $5.9 \%$ from the income tax). Some part of premiums and taxes of the tax wedge finance the public healthcare system. In this situation, by the relative low GDP per capita for Poland, Poles have less private funds for disposal. In the opinion of the representatives of the insurance industry, one of the factors hindering the development of the health insurances is the broad range of the financial services from public funds and funds guaranteed by law for all residents, what limits the space for the development of the supplementary insurances (so-called crowding out effect) ${ }^{17}$. The level of the tax wedges and GDP per capita of the individual countries are shown in Figure 8.

Relatively low level of trust to the insurance companies. In spite of the fact that the private insurances lead to gradual change in the perception of the insurers, in Poland, they still do not have sufficiently good opinion as in the Western European countries. This situation results to a certain extent from the historical factors. Western European countries have stronger liberal traditions, because they experienced benefits from the liberal politics and the capital economy raised in the 19th century within it. During this period, Poland lost its sovereignty, regained it only in 1918 and lost its independence again from the second half of the 20th century, and found herself in the influence sphere of the foreign totalitarian system of Union of Soviet Socialist Republics (USSR). Under such historical circumstances, it was difficult to develop the private market based on the private property or freedom of contract. In the socialist system that was functioning in Poland in the second half of the 20th century, there was no place for private insurances and the healthcare system was an element of central planning.

Some economists point out that most countries enslaved by the Soviet empire moved out of a fully socialized system through privatization and insuring competition in the healthcare system (Maltsev, 2012). Last 25 years of the economic transformation in Poland did not suddenly change the attitude of the society on perception of the private insurances after about 50 years of political and economic turbulences. Therefore, no wonder that people, for example, because of their low income cannot afford purchasing a private insurance, do not recognize benefits from having it, what to some extent can influence the lack of trust to private insurance institutions. The level of trust to insurance companies is presented in Table 1 and Table 2.

Study from the year 2007 showed trust to life insurance institutions at the level of 49\% (2005-43\%; $2003-39 \%)$ and trust to wealth insurance institutions at the level of $34 \%(2005-28 \% ; 2003-27 \%)$. Therefore, we can speak about a significant decline of trust to the insurance companies (Szumlicz, 2011). In the study from the year 2013, different kinds of answers were set more detailed, what could in some way influence the results. As one of the reasons of the trust decline to the insurance institutions counts the financial crisis from 2008 and its results. Lower pace of the economic growth or growth of unemployment in the United States and

${ }_{17}$ See: Outline of the healthcare system. Poland 2012, p. 107. Retrieved from http://www.nfz.gov.pl/akademia/pliki/Polska_ 2012.pdf. 
Europe may be negatively associated with the activity of big financial institutions. The level of trust before the crisis (from the years 2003 and 2005) was relatively higher than now, what leads to the conclusion that the improvement of the economic situation in Europe may influence the raise of trust positively and its deterioration (e.g., as a result of the withdrawal of Greece from the EU) may influence its further decline or keeping at the same level.

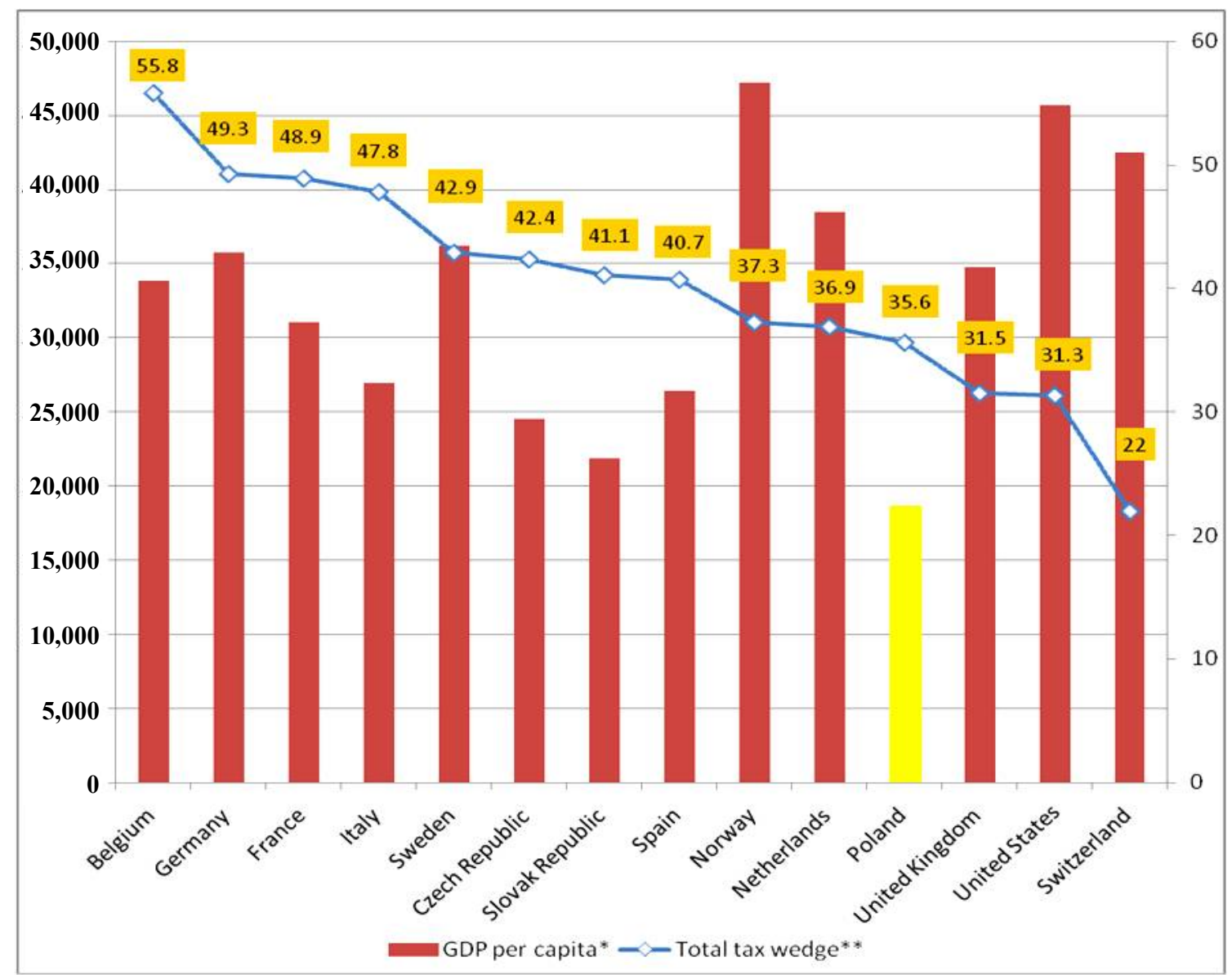

Figure 8. Comparison of GDP per capita (left scale) and total tax wedge (right scale) of the chosen countries in 2013. Sources: see the websites ${ }^{18}{ }^{19}$. Notes. ${ }^{*}-$ GDP per capita according to the purchasing power parity in USD; ${ }^{* *}$-total tax wedge as $\%$ of labor costs.

Table 1

General Level of Trust to the Insurance Companies in Poland 2013

\begin{tabular}{lllll}
\hline Specification (in percentage) & Yes (high) & Yes (moderate) & No & I do not have any opinion \\
\hline Life insurance companies & 1.5 & 29.4 & 34.3 & 34.8 \\
Wealth insurance companies & 1.3 & 25.9 & 33.9 & 38.9 \\
\hline
\end{tabular}

Note. Source: Szumlicz (2013) ${ }^{20}$.

\footnotetext{
${ }^{18}$ See: OECD taxing wages 2014, p. 12. Retrieved from http://www.keepeek.com/Digital-Asset-Management/oecd/taxation/ taxing-wages-2014_tax_wages-2014-en\#page3.

19 See: Level of GDP per capita and productivity. Retrieved from http://stats.oecd.org/Index.aspx?DataSetCode=PDB_LV.

20 See: Szumlicz, T. (2013). Trust to the insurance institutions in the light of the social diagnosis 2013 against a background of the other financial institutions. Insurance News, 3, 103-118. Retrieved from https://www.piu.org.pl/public/upload/ibrowser/ Wiadomosci\%20Ubezpieczeniowe/WU\%2032013/WU\%203-2013\%20E\%20szumlicz.pdf.
} 
Table 2

General Level of Trust to the Insurance Companies in Poland 2011

\begin{tabular}{llll}
\hline Specification (in percentage) & Yes & No & I do not have any opinion \\
\hline Insurance companies in general & 14.1 & 39.6 & 46.3 \\
\hline Note. Source: Szumlicz $(2011)^{21}$. & & &
\end{tabular}

\section{Conclusions}

The market of private health insurance in Poland has a big development potential. Following facts speak in favor of it. The pace of demand growth on a yearly average in the last several years indicates a need for this form of financing of the access to the medical services. Moreover, the public system is evaluated poorly by Poles as well as in the international comparative rankings. Additional problem constitutes the aging society that will raise more and more demand for the private medical services, what in case of public systems will strengthen the pressure to raise premiums and taxes. In the analysis of the possibilities to provide services by the private institutions, we have to take into account that free institutions do not have to be ideally delineated. They arise from spontaneous order in the absence of or in the vacuum of the retreating state (Steinreich, 2006). Therefore, it is important to create adequate conditions for such institutions to act, eliminate obstacles, instead of deciding from above by legislation on scope and rules of operations.

\section{References}

Central Statistical Office. (2013). Area and population in the territorial profile in 2013. Retrieved from http://stat.gov.pl/cps/rde/ $\mathrm{xbcr} / \mathrm{gus} / \mathrm{p} \_$area_and_population_in_the_territorial_profile_2013.pdf

Ernst \& Young. (2013). Role and functioning of the additional health insurance in the contemporary healthcare systems-Analysis and recommendations for Poland. Polish Insurance Association. Retrieved from http://gu.com.pl/ static/czol-raport.pdf

Głowacka, M. D., \& Zdanowska, J. (2013). Public health in Poland. Warsaw: Wolters Kluwer.

Handschke, J. (Ed.). (2013). Insurances in the healthcare system. Insurances in the social and economic development of Poland (pp. 73-74). Warsaw: Polish Insurance Association.

Health at Glance 2014. (2014). OECD report. Retrieved from http://www.oecd-ilibrary.org/social-issues-migrationhealth/health-at-a-glance-europe-2014_health_glance_eur-2014-en

Health Consumer Powerhouse. (2015). Eurohealth consumer index 2014. Retrieved from http://www.healthpowerhouse.com/ files/EHCI_2014/EHCI_2014_Index_matrix_A3_sheet.pdf

Insurance companies with headquarters in Poland. (2015). Retrieved from http://www.knf.gov.pl/en/about_the_market/ Insurance/Insurance_companies/Life_insurance_companies/insurance_companies.html

Iwanicz-Drozdowska, M. (Ed.). (2013). Insurance. Warsaw: Polish Economic Publishing House.

Maltsev, Y. N. (2012). What soviet medicine teaches us? Retrieved from http://mises.org/library/what-soviet- medicine-teaches-us

Market of the private healthcare in Poland: Growth by 5\% in 2012-2014. (2012). PMR. Retrieved from https://www. pmrpublications.com/press-releases/336/rynek-prywatnej-opieki-zdrowotnej-w-polsce-wzrost-o-5-w-latach-2012-2014

Non-life insurance companies with headquarters in Poland. (2015). Retrieved from http://www.knf.gov.pl/ en/about_the_market/Insurance/Insurance_companies/Non_life_insurance_companies/non_life_insurance_companies.html

Outline of the healthcare system. Polska 2012. (2012). In S. Golinowska (Ed.), Poland: Health system review. World Health Organization. Retrieved from http://akademia.nfz.gov.pl/wp-content/uploads/2013/08/HiT_Polska_2012_z_okladka_ automatyczny_spis_tresci.pdf

Pantelli, D., \& Sagan, A. (Eds.). (2011). Poland: Health system review. Health Systems in Transition, 13(8), 1-193. Retrieved from http://www.euro.who.int/_data/assets/pdf_file/0018/163053/e96443.pdf

${ }^{21}$ See: Szumlicz, T. (2011). Social trust to the insurance institutions. Insurance News, 3, 113-118. Retrieved from https://www. piu.org.pl/public/upload/ibrowser/WU/WU3_2011/szumlicz.pdf. 
Role of the private health insurance in the healthcare system. How do they influence the access to services, innovations and medicines-Key theories and recommendations. (2011). Polish Insurance Association. Retrieved from https://piu.org.pl/ public/upload/ibrowser/110908_PIU_Infarma_Sequence_opracowanie_dodatkowe_ubezpieczenia.pdf

Steinreich, D. (2006). Lives at risk: Single-payer national health insurance around the world. Book review. Quarterly of Austrian Economics, 9(3), 75-85.

Supplementary benefits in the eyes of the employees in 2014. (2014). Cracow: Sedlak \& Sedlak.

Surmacz, W. (2012). Money for health. Market of medical services in Poland. Forbes report (pp. 14-15). Warsaw.

Szumlicz, T. (2011). Social trust to insurance institutions. Insurance News, 3, 113-118.

Szumlicz, T. (2013). Trust to the insurance institutions in the light of the social diagnosis 2013 against a background of the other financial institutions. Insurance News, 3, 103-118.

Taxing wages 2014. (2014). OECD report. Retrieved from http://dx.doi.org/10.1787/tax_wages-2014-en 